\title{
Impact of Milk Protein Type on the Viability and Storage Stability of Microencapsulated Lactobacillus acidophilus NCIMB 701748 Using Spray Drying
}

\author{
Christos Soukoulis • Solmaz Behboudi-Jobbehdar \\ Lina Yonekura • Christopher Parmenter • Ian Fisk
}

Received: 31 January 2013 / Accepted: 25 April 2013 /Published online: 15 May 2013

(C) The Author(s) 2013. This article is published with open access at Springerlink.com

\begin{abstract}
Three different milk proteins - skim milk powder (SMP), sodium caseinate (SC) and whey protein concentrate (WPC) - were tested for their ability to stabilize microencapsulated L. acidophilus produced using spray drying. Maltodextrin (MD) was used as the primary wall material in all samples, milk protein as the secondary wall material (7:3 MD/milk protein ratio) and the simple sugars, D-glucose and trehalose were used as tertiary wall materials $(8: 2: 2$ $\mathrm{MD} /$ protein/sugar ratio) combinations of all wall materials were tested for their ability to enhance the microbial and techno-functional stability of microencapsulated powders. Of the optional secondary wall materials, WPC improved $L$. acidophilus viability, up to $70 \%$ during drying; SMP enhanced stability by up to $59 \%$ and SC up to $6 \%$. Lactose and whey protein content enhanced thermoprotection; this is possibly due to their ability to depress the glass transition and melting temperatures and to release antioxidants. The resultant L. acidophilus powders were stored for 90 days at $4{ }^{\circ} \mathrm{C}, 25^{\circ} \mathrm{C}$ and $35^{\circ} \mathrm{C}$ and the loss of viability calculated. The highest survival rates were obtained at $4{ }^{\circ} \mathrm{C}$, inactivation rates for storage were dependent on the carrier wall material and the SMP/D-glucose powders had the lowest inactivation rates $\left(0.013\right.$ day $\left.^{-1}\right)$ whilst the highest was observed for the control containing only MD $\left(0.041\right.$ day $\left.^{-1}\right)$ and the SC-based system $\left(0.030\right.$ day $\left.^{-1}\right)$. Further increase in storage temperature $\left(25^{\circ} \mathrm{C}\right.$ and $35^{\circ} \mathrm{C}$ ) was accompanied by increase of the inactivation
\end{abstract}

C. Soukoulis $\cdot$ S. Behboudi-Jobbehdar $\cdot$ L. Yonekura $\cdot$ I. Fisk $(\bowtie)$ Division of Food Sciences, School of Biosciences, University of Nottingham, Sutton Bonington Campus, Loughborough,

Leicestershire LE12 5RD, UK

e-mail: Ian.Fisk@nottingham.ac.uk

C. Parmenter

Nottingham Nanotechnology and Nanoscience Centre, University of Nottingham, University Park, Nottingham NG7 2RD, UK rates of L. acidophilus that followed Arrhenius kinetics. In general, SMP-based formulations exhibited the highest temperature dependency whilst WPC the lowest. D-Glucose addition improved the storage stability of the probiotic powders although it was accompanied by an increase of the residual moisture, water activity and hygroscopicity, and a reduction of the glass transition temperature in the tested systems.

Keywords Probiotics · Storage stability · Thermoprotection · Sugars

\section{Introduction}

Probiotics are live organisms that when administered in adequate amounts ( $>7 \log \mathrm{CFU} / \mathrm{g}$ ) confer health benefits to the host (FAO/WHO 2006). Bacteria belonging to the Lactobacilli genera such as L. acidophilus, L. rhamnosus, $L$. casei, and $L$. plantarum are among the most common probiotic microorganisms with established benefits to the human host (Saad et al. 2013). Claimed benefits include regulation of the gastrointestinal tract, stimulation of the immune system, reduction of serum cholesterol levels and lactose intolerance and prevention of cancer and cardiovascular disease (Cho \& Finocchiaro 2010). The constantly increasing consumers' expectation for healthy and nutritious foods with customized functional and physiological aspects has forced the food industry to develop new strategies to incorporate probiotics into real food systems whilst retaining viability over harsh processing and storage conditions. A broad range of food products including fermented milks (Dave and Shah 1998), frozen dairy desserts and milk products (Cruz et al. 2009; Malmo et al. 2011), cheese, oil/water emulsions and dressings (Mantzouridou et al. 2012), water/oil-based emulsions (Pérez-Chabela et al. 
2012), low-fat spreads (Dommels et al. 2009) breakfast cereals (Saarela et al. 2006), infant food (Salminen et al. 2009), milk and fruit beverages (Rodrigues et al. 2012) have been evaluated as potential vehicles for the delivery of probiotic functionality to the human host.

The micro-entrapment of probiotic cells in biopolymer substrates using mechanical or physicochemical processes such as dehydration, emulsification, extrusion, gelation, coacervation is commonly applied strategy for the production of viable dry probiotic formulations (Burgain et al. 2011). With respect to the dehydration techniques, freeze drying (Heidebach et al. 2009; Heidebach et al. 2010; Saarela et al. 2006), spray drying (Gardiner et al. 2000; Corcoran et al. 2004; Pinto et al. 2012; Fritzen-Freire et al. 2012) vacuum drying (Santivarangkna et al. 2006), air convective drying (Ghandi et al. 2012) and fluidized bed drying dehydration are the most commonly used approaches for the production and stabilization of dry probiotic powders. Although spray drying is believed to induce significant heat stress related injuries to thermally labile lactic acid bacteria such as $L$. acidophilus or L. rhamnosus strains, its application for the production of dried culture starters and probiotics has become very popular over the last years mainly due to its low cost and easy production (Burgain et al. 2011).

Intrinsic (species and strain type, culture growth stage, subcellular heat and osmotic stress injuries) and extrinsic factors (spray dryer operating conditions, pre-processing of the culture media and encapsulation carriers) can significantly impact the viability and acidification ability of spray dried probiotic bacteria (Fu \& Chen 2011; Champagne et al. 2011; Corcoran et al. 2004). Excessive heating during spray drying (e.g., high inlet and outlet temperatures, low feed flow rates, high total solids concentration of the drying medium) can lead to cellular heat damage such as unfolding of the high order macromolecular conformations (proteins and nucleic acids), modification of the physical state of the cytoplasmic membranes and peroxidation of the membrane lipid bilayers (Corcoran et al. 2008; Fu \& Chen 2011; Gardiner et al. 2000; Ananta et al. 2005). Some lactobacilli strains have greater heat resistance, this is strictly strainspecific with lactobacilli belonging to the $L$. plantarum, $L$. salivarius and $L$. paracasei species characterized as having greater thermotolerance (up to $80 \%$ ) throughout spray drying (Gardiner et al. 2000; Reddy et al. 2009).

Starch derivatives such as maltodextrins (MD), modified starches and corn syrup solids can be used as the primary wall material for anhydrobiotics (viable probiotics in a dried format) production. Polysaccharides and proteins may also be combined with starch derivatives to improve the interfacial properties required for achieving effective microencapsulation (Gharsallaoui et al. 2007). The composition of the drying media may be modified to reduce the heat and osmotic stress received by the bacterial cells during drying.
This may include the incorporation of low molecular weight carbohydrates in the drying carrier such as sugars and polyols (Burgain et al. 2011). Two mechanisms have been suggested to explain the thermoprotective action of sugars: chemical reaction between sugars and cellular membranes and the reduction of the thermal and osmotic stress experienced by the bacteria during the dehydration process by stabilization of the original liquid crystalline structure of the membrane's lipid bilayer (Fu \& Chen 2011). Dissacharides such as trehalose, sucrose and lactose have been used successfully as thermoprotectans during spray drying of L. rhamnosus GG, L. plantarum TISTR 2075, L. paracasei (Sunny-Roberts \& Knorr 2009; Lapsiri et al. 2012; Semyonov et al. 2011). Moreover, the addition of proteins such as skim milk powder (SMP) or whey protein isolates can also promote thermoprotection during spray drying of lactobacilli (Ananta et al. 2005; Ying et al. 2012; Fritzen-Freire et al. 2012; Gardiner et al. 2000).

The use of macromolecular ingredients has been also suggested to stabilize viable bacteria during storage mainly due to their ability to impact the physicochemical properties of the dried carrier matrices, i.e., water activity, residual moisture content, glass transition temperature, molecular water mobility and diffusion (Fu \& Chen 2011; Roos 1995; Santivarangkna et al. 2011). Low water mobility due to steric constraints, e.g., glassy state can slow down the metabolic activity of the cells (Santivarangkna et al. 2011). Ying et al. (2012) investigating the effects of the relative humidity of storage environment and the physical state (e.g., rubbery or glassy) of the carrier on the viability of spray dried L. rhamnosus GG reported a nearly 10 -fold reduction in the viable counts when stored in the rubbery state $(75 \%$ $\mathrm{RH})$ compared to glassy state systems stored at low water activities (11\% RH).

Although the intelligent selection of spray dried carriers such as maltodextins, starch hydrolyzates, oligosaccharides, dietary fiber and sugars has been shown to stabilize a wide range of probiotic bacteria, the impact of milk proteins inclusion with varying lactose, casein and whey proteins content has not yet been fully studied. The aim of the present work was the comparative study of the effects of three different milk proteins namely whey protein concentrate (WPC), SMP and sodium caseinate (SC) on the functional, structural and storage stability properties of spraydried powders containing L. acidophilus NCIMB 701648.

\section{Materials and Methods}

Materials

Maltodextrin 15 DE (C* Dry MD 01910), WPC (79-83\% protein, $9 \%$ lactose; Lacprodan ${ }^{\circledR}$ DI-8090) and anhydrous 
trehalose $\left(\mathrm{Treha}^{\mathrm{TM}}\right)$ were kindly provided as a gift from Cargill Ltd. (Manchester, UK), Arla Ltd. (Viby, Denmark) and Hayashibara Ltd. (Okayama, Japan) respectively. SC (99\% sodium caseinate, $<0.1 \%$ lactose; Acros Organics), D-glucose (Fisher Chemicals) and lithium chloride (Acros Organics) were purchased from Fisher Scientific Ltd. (Loughborough, UK). SMP (34-37\% protein, lactose 50-52 \%) was purchased commercially (Brakes Bros Ltd., Ashford, Kent, UK).

\section{Bacterial Strain and Growth Conditions}

Lactobacillus acidophilus NCIMB 701748 was purchased from NCIMB (Aberdeen, Scotland, UK). An MRS-agar plate was streaked for isolation from the frozen stock and incubated at $37{ }^{\circ} \mathrm{C}$ with $5 \% \mathrm{CO}_{2}$ for $24 \mathrm{~h}$ to ensure purity. A small amount of the colonies was collected with a sterilized loop and consequently suspended in the cryo-medium of Roti ${ }^{\circledR}$-Store systems (Roti ${ }^{\circledR}$-Store; Carl-Roth GmbH, Karlsruhe, Germany) and the plastic bead cultures were stored in a freezer at $-80{ }^{\circ} \mathrm{C}$ (Ananta et al. 2005).

\section{Preparation of the Drying Media}

One bead of the deep frozen cultures were placed in MRS broth (Oxoid Ltd., Basingstoke, UK) and incubated for $48 \mathrm{~h}$ at $37{ }^{\circ} \mathrm{C}$ under anaerobic conditions in plastic jars containing AnaeroGen (Oxoid Ltd.). The final broth was transferred under aseptic conditions into $50-\mathrm{ml}$ sterile centrifuge tubes (Sarstedt $\mathrm{GmbH}$, Leicester, UK) and centrifuged at $3,000 \times \mathrm{g}$ for $5 \mathrm{~min}$. After centrifugation, the supernatant was discarded and the harvested cells in the form of pellets were washed once using phosphate buffer saline pH 7.0 (Dulbecco A PBS; Oxoid Ltd.). The cell suspensions were centrifuged as previously, after discarding the supernatant, the pellets were suspended into the drying carrier solutions. The compositional profile of the drying carrier aliquots are given in Table 1 . The dry ingredients were blended together and dispersed in cold water under magnetic stirring. The ingredients were left to fully hydrate for $1 \mathrm{~h}$ at room temperature under continuous agitation and

Table 1 Formulations of L. acidophilus NCIMB 701748 spray dried powders $(\% \mathrm{w} / \mathrm{w})$

\begin{tabular}{llll}
\hline Encapsulant formulation & Maltodextrin 15DE & Protein & Sugar \\
\hline Control (MD) & 100 & - & - \\
$\mathrm{MD} / \mathrm{P}^{\mathrm{a}}$ & 70 & 30 & - \\
$\mathrm{MD} / \mathrm{P} / \mathrm{S}^{\mathrm{b}}$ & 60 & 20 & 20 \\
\hline
\end{tabular}

${ }^{a} \mathrm{P}$ refers to exclusively one type of milk protein, e.g., skim milk powder, whey protein concentrate or sodium caseinate

${ }^{\mathrm{b}} \mathrm{S}$ refers to exclusively one type of sugar, e.g., D-glucose or trehalose then, the solutions were heat treated at $90{ }^{\circ} \mathrm{C}$ for $10 \mathrm{~min}$ to destroy pathogens and allow full protein denaturation. The carbohydrate-protein solutions were rapidly cooled at room temperature using an ice bath and inoculated with the $L$. acidophilus pellets.

Spray Drying and Storage of Probiotic Powders

The inoculated media with $L$. acidophilus was dried using a Buchi B-290 laboratory spray dryer (Buchi, Flawil, Switzerland). The spray dryer was operated under optimized inlet temperature and feeding rate conditions in terms of maximal strain survival and minimal moisture content in the final product (BehboudiJobbedhar et al. 2013). More specifically, the spray dryer was operated at constant inlet temperature of $134 \pm 1{ }^{\circ} \mathrm{C}$, feed flow rate of $7.14 \mathrm{ml} \mathrm{min}^{-1}$, drying air flow rate of $35 \mathrm{~m}^{3} \mathrm{~h}^{-1}$, and compressor air pressure of $0.5 \mathrm{MPa}$. The outlet temperature achieved was $76 \pm 2{ }^{\circ} \mathrm{C}$ whereas the carrier aliquot was kept under agitation throughout the spray drying process using a magnetic stirrer.

The dry probiotic formulations were collected from the cyclone, placed in sealed glass vials and stored at three different temperatures $\left(4{ }^{\circ} \mathrm{C}, 25^{\circ} \mathrm{C}\right.$ and $\left.35^{\circ} \mathrm{C}\right)$ in desiccators containing saturated lithium chloride $(\mathrm{LiCl})$ solutions to provide dry conditions $\left(a_{\mathrm{w}}=0.11\right)$.

\section{Enumeration of the Bacteria}

The L. acidophilus microcapsule powders as well as the drying media aliquots were suspended and diluted in phosphate buffer saline (Dulbecco A PBS; Oxoid Ltd.) under constant shaking for $10 \mathrm{~min}$ at room temperature to ensure complete dissolution of the powders. The resulting samples were subjected to serial dilutions using phosphate buffer saline. Each dilution was pour plated on a MRS agar (MRS Agar; Oxoid Ltd.) and the plates were stored at $37^{\circ} \mathrm{C}$ for $72 \mathrm{~h}$ under anaerobic conditions to allow colonies to grow. Enumeration of the bacteria was performed in triplicate following the standard plating methodology (Champagne et al. 2011) and the total counts of the viable bacteria were expressed as log colony forming units per gram $(\mathrm{CFU} / \mathrm{g})$.

The survival rate of the bacteria after the spray drying process was calculated according to the formula:

$\%$ viability $=100 \times \frac{\mathrm{N}}{\mathrm{N}_{0}}$

where $N_{0}$ and $N$ represent the number of viable bacteria prior and after the spray drying process, respectively (Ananta et al. 2005). 
The L. acidophilus inactivation upon storage data was expressed as the logarithmic value of the relative viability fraction $\left(\log N / N_{0}\right)$. The viability data were fitted to a first order reaction kinetics model as described by the formula:

$\log \mathrm{N}_{\mathrm{t}}=\log \mathrm{N}_{0}+\mathrm{k}_{\mathrm{T}} \mathrm{t}$

where $N_{0}$ represents the initial number of the viable bacteria and $N_{\mathrm{t}}$ is the number of viable bacteria after a specific time of storage (in CFU/g), $t$ is the storage time (in days), and $k_{\mathrm{T}}$ is the inactivation rate constant at $T$ temperature $\left(\right.$ day $\left.^{-1}\right)$. The obtained $k_{\mathrm{T}}$ values were fitted to the Arrhenius equation for determining the dependence of viability loss on storage temperature (Lapsiri et al. 2012):

$\log \mathrm{k}=\log \mathrm{k}_{0}-\frac{\mathrm{E}_{\mathrm{a}}}{2.303 R} \times \frac{1}{\mathrm{~T}}$

where $k$ is the specific rate of degradation $\left(\right.$ day $\left.^{-1}\right), E_{\mathrm{a}}$ is the activation energy $\left(\mathrm{kJ} \mathrm{mol}^{-1}\right), R$ is the universal gas constant $\left(8.314 \mathrm{~J} \mathrm{~mol}^{-1} \mathrm{~K}^{-1}\right)$ and $T$ is the absolute temperature $(\mathrm{K})$.

Powder Characterization

\section{Residual Water Content and Water Activity}

The residual water content was calculated according to AACC method 44-1502. Very briefly, $2 \mathrm{~g}$ samples of the powder formulations were placed in aluminum pans and dried at $105{ }^{\circ} \mathrm{C}$ for $24 \mathrm{~h}$. Residual water content has been calculated according to formula:

$\%$ residual water content $=100 \times \frac{\mathrm{w}_{\mathrm{f}}-\mathrm{w}_{\mathrm{i}}}{\mathrm{w}_{\mathrm{i}}}$

where $w_{\mathrm{i}}$ and $w_{\mathrm{f}}$ are the weights of the dry probiotic formulations prior and after dehydration at $105^{\circ} \mathrm{C}$, respectively.

Water activity of the powders after the spray drying was measured using an AquaLab water activity meter (AquaLab, 3TE, Decagon, USA)

\section{Differential Scanning Calorimetry}

A standard power compensated Perkin Elmer DSC-7 (Perkin Elmer Ltd., Beaconsfield, UK) was used for the determination of glass transition temperature of the probiotic formulations. A small portion $(10-20 \mathrm{mg}$ ) of the powder was weighed in a high pressure, stainless steel pan and heated from $-30{ }^{\circ} \mathrm{C}$ to $150{ }^{\circ} \mathrm{C}$ at the rate of $10{ }^{\circ} \mathrm{C} / \mathrm{min}$. A double heating-cooling scanning step was performed, and thermal properties (onset, midpoint and offset glass transition temperatures) were calculated using the Mettler Toledo Star software from the second heating step thermographs.

\section{Particle Mean Size Analysis}

The particle mean size analysis was performed on laser diffraction particle size analyzer equipped with the Tornado dry powder system (LS 13320; Beckman Coulter, USA). The Fraunhofer theory was used for the determination of the mean diameters of the microcapsules:

$\sin \theta=\frac{1.22 \lambda}{d}$

where $\lambda$ is the laser light wavelength and $d$ is the particle diameter. The volume distributions of the samples were calculated and the results are presented as mean particle size diameter $\left(d_{\mathrm{v}, 50}\right)$.

\section{Color Measurement}

One gram of powder was placed in plastic cuvettes and color measurements were performed using a Hunterlab (Reston, USA) colorimeter. The CIELab color scale was used to measure the $L^{*}$ (black to white), $a^{*}$ (red to green), and $b^{*}$ (yellow to blue) parameters. The total color difference $\Delta E^{*}$ between the control sample (MD) and each individual dry probiotic formulation was calculated according to the formula:

$\Delta \mathrm{E}^{*}=\left[\left(\Delta \mathrm{L}^{*}\right)^{2}+\left(\Delta \mathrm{a}^{*}\right)^{2}+\left(\Delta \mathrm{b}^{*}\right)^{2}\right]^{1 / 2}$

where $\Delta L^{*}, \Delta a^{*}$ and $\Delta b^{*}$ are the brightness, redness and yellowness intensity difference from the control sample, respectively (Fritzen-Freire et al., 2012).

\section{Hygroscopicity}

The hygroscopicity of the probiotic powders was determined according to the procedure described by Fritzen-Freire et al. (2012). More specifically, $1 \mathrm{~g}$ samples of the powders were placed in a desiccator equilibrated at $75 \% \mathrm{RH}$ containing a saturated sodium chloride $(\mathrm{NaCl})$ solution at room temperature. Samples were kept for 7 days and hygroscopicity was calculated gravimetrically according to the formula:

hygroscopicity ( $g$ of $\mathrm{H}_{2} \mathrm{O}$ perg of product)

$$
=100 \times \frac{\mathrm{m}_{\mathrm{f}}-\mathrm{m}_{\mathrm{i}}}{\mathrm{m}_{\mathrm{i}}}
$$

where $m_{\mathrm{i}}$ and $m_{\mathrm{f}}$ express the moisture of the samples prior and after the storage at $75 \% \mathrm{RH}$, respectively.

\section{Morphological Characterization}

A small amount of powder was carefully deposited onto carbon tabs (Agar Scientific, Stansted, UK) and coated with carbon (Agar turbo carbon coater) to improve conductivity. 
The scanning electron microscope analysis (SEM) was performed on a FEI Quanta 3D 200 dual beam focused Ion Beam Scanning Electron Microscope (FIB-SEM). The images were acquired using secondary electron imaging at an accelerating voltage of $5-15 \mathrm{kV}$.

\section{Statistical Analysis}

Two-way ANOVA followed by Duncan's post-hoc means comparison $(p<0.05)$ test was performed to evaluate the main effects of the investigated factors (milk protein type and sugar type) on the physicochemical and microbiological data, ANOVA was conducted by excluding the MD only powder to maintain a full experimental design. Linear correlation (Pearson's correlation coefficients, $p<0.05$ ) was applied on the k-rates and thermal analysis data to investigate interrelationships. All statistical calculations were performed using the MINITAB release 16 (Minitab Inc., Pennsylvania, USA), statistical software.

\section{Results and Discussion}

Characterization of the Physicochemical Properties of the Probiotic Powders

\section{Residual Water Content and Water Activity}

The residual water content of the powders after drying was significantly influenced $(p<0.001)$ by the milk protein type. Generally, the SMP-based formulations were characterized as having the highest water activity and water content values, whereas the SC containing formulations had the lowest (Table 2). In principal, the moisture of the spray dried products is related to the processing conditions (inlet temperature and feeding rate) and carrier composition (Barbosa-Cánovas et al. 2005). Lactose and mineral salts are considered hygroscopic materials which retard water loss during drying and results in higher final moisture content in the case of protein-based spray dried products (Shrestha et al. 2008). The remarkably low lactose concentration of SC (less than $0.1 \%$ ) seems to be associated with the low moisture and $\mathrm{a}_{\mathrm{w}}$ values of the corresponding microcapsules. Indeed, the gradual increase of lactose content in the case of WPC (approx. $9 \% \mathrm{w} / \mathrm{w}$ ) and SMP (approx. $51 \% \mathrm{w} / \mathrm{w}$ ) was also accompanied by a significant increase $(p<0.001)$ of the microcapsules residual water contents. Similar values of moisture and water activities in the case of SMP and WP-based microcapsules containing bifidobacteria have been also reported by Fritzen-Freire et al. (2012) and De Castro-Cislaghi et al. (2012). The addition of D-glucose induced a significant increase of the moisture content regardless of the milk protein type. In contrast to trehalose, the ability of D-glucose to easily absorb water explains the elevated moisture and $\mathrm{a}_{\mathrm{w}}$ values of the microcapsules. However, the moisture content of all systems was found to be within the acceptable limits of residual moisture for food powders $(<5 \%)$ indicating good shelf-life stability (Ananta et al. 2005).

\section{Hygroscopicity}

Water uptake is related with environmental conditions (storage temperature and relative humidity levels) but also with the structural and compositional aspects of the matrices. The gradual increase of the water content through vapor diffusion at the solid-air interface will result in plasticization and eventually in a glassy to rubbery state transition (Roos 1995). As a direct result of the increased water mobility enzymatic or

Table 2 Effect of the matrix wall composition on physical and technological properties of the spray dried powders containing L. acidophilus NCIMB 701748

\begin{tabular}{|c|c|c|c|c|}
\hline $\begin{array}{l}\text { Spray drying } \\
\text { medium }\end{array}$ & Water activity & $\begin{array}{l}\text { Residual water content } \\
(\mathrm{g} / 100 \mathrm{~g})\end{array}$ & $\begin{array}{l}\text { Hygroscopicity } \\
\text { ( } \mathrm{g} \mathrm{H}_{2} \mathrm{O} / \mathrm{g} \text { of powder) }\end{array}$ & $\begin{array}{l}\text { Particle mean size, } \\
D[\mathrm{v}, 50](\mu \mathrm{m})\end{array}$ \\
\hline MD & $0.16 \pm 0.01^{\mathrm{c}}$ & $3.20 \pm 0.11^{\mathrm{d}}$ & $0.108 \pm 0.001^{\mathrm{b}}$ & $10.75 \pm 0.23^{b}$ \\
\hline $\mathrm{MD} / \mathrm{SMP}$ & $0.23 \pm 0.01^{\mathrm{e}}$ & $4.01 \pm 0.08^{\mathrm{f}}$ & $0.142 \pm 0.002^{\mathrm{e}}$ & $11.58 \pm 0.27^{\mathrm{c}}$ \\
\hline $\mathrm{MD} / \mathrm{SMP} / \mathrm{G}$ & $0.27 \pm 0.02^{\mathrm{f}}$ & $4.19 \pm 0.03^{\mathrm{g}}$ & $0.194 \pm 0.001^{\mathrm{i}}$ & $9.38 \pm 0.05^{\mathrm{a}}$ \\
\hline $\mathrm{MD} / \mathrm{SMP} / \mathrm{T}$ & $0.25 \pm 0.00^{\mathrm{g}}$ & $4.12 \pm 0.01^{\mathrm{g}}$ & $0.146 \pm 0.000^{\mathrm{f}}$ & $11.92 \pm 0.07^{\mathrm{c}}$ \\
\hline $\mathrm{MD} / \mathrm{WPC}$ & $0.18 \pm 0.00^{\mathrm{de}}$ & $3.71 \pm 0.06^{\mathrm{e}}$ & $0.107 \pm 0.001^{\mathrm{b}}$ & $12.34 \pm 0.06^{\mathrm{d}}$ \\
\hline $\mathrm{MD} / \mathrm{WPC} / \mathrm{G}$ & $0.22 \pm 0.02^{\mathrm{d}}$ & $3.93 \pm 0.01^{\mathrm{f}}$ & $0.174 \pm 0.001^{\mathrm{h}}$ & $10.96 \pm 0.63^{b}$ \\
\hline $\mathrm{MD} / \mathrm{WPC} / \mathrm{T}$ & $0.19 \pm 0.01^{\mathrm{d}}$ & $3.76 \pm 0.04^{\mathrm{e}}$ & $0.129 \pm 0.000^{\mathrm{d}}$ & $12.78 \pm 0.71^{\text {cde }}$ \\
\hline $\mathrm{MD} / \mathrm{SC}$ & $0.10 \pm 0.00^{\mathrm{a}}$ & $1.66 \pm 0.04^{\mathrm{a}}$ & $0.100 \pm 0.003^{\mathrm{a}}$ & $13.37 \pm 0.04^{\mathrm{e}}$ \\
\hline $\mathrm{MD} / \mathrm{SC} / \mathrm{G}$ & $0.14 \pm 0.01^{\mathrm{c}}$ & $2.68 \pm 0.09^{\mathrm{c}}$ & $0.162 \pm 0.000^{\mathrm{g}}$ & $11.71 \pm 0.23^{\mathrm{c}}$ \\
\hline $\mathrm{MD} / \mathrm{SC} / \mathrm{T}$ & $0.12 \pm 0.00^{\mathrm{b}}$ & $2.17 \pm 0.02^{\mathrm{b}}$ & $0.117 \pm 0.003^{c}$ & $12.04 \pm 0.27^{\mathrm{d}}$ \\
\hline
\end{tabular}

Different letters between rows indicate significant difference according to Duncan's mean post-hoc comparison test $(p<0.05)$

$M D$ maltodextrin $15 \mathrm{DE}, W P C$ whey protein concentrate, $S M P$ skim milk powder, $S C$ sodium caseinate, $G$ glucose, $T$ trehalose 
chemical reactions can take place leading more quickly to quality deterioration and modification of the physical properties (stickiness, flowability, agglomeration) of the final product (Barbosa-Cánovas et al. 2005). Hygroscopicity of the microcapsules was significantly influenced by both milk protein and sugar type added (ANOVA, $p<0.001$ ). Generally, the presence of the milk protein was associated with elevated hygroscopicity levels with SMP-based powders able to take up the highest amount of water (Table 2). The high hygroscopicity of lactose combined with its increased ability to bind water when found in the glassy state can primarily explain the former observations. Similarly to the residual moisture content and $a_{\mathrm{w}}$ results, hygroscopicity of D-glucose powders was significantly higher than that of the control or trehalose containing powders (ANOVA, $p<0.05$ ). Of the three sugars present (lactose, trehalose and glucose), glucose is the most hygroscopic which promoted increased water uptake through the formation of weak intermolecular hydrogen bonds (Jayasundera et al. 2009; O’Brien-Nabors 2012).

\section{Particle Size Analysis}

The particle mean size distributions of the microcapsules in the presence or absence of milk proteins are shown in Fig. 1. In the case of MD, WPC and SC spray-dried powders, the particles had a bimodal particle size distribution with two distinct peaks, whereas in the case of SMP a third peak was detected in the region of 40-90 $\mu \mathrm{m}$. Generally, powders with bimodal particle mean size distributions are characterized by lower space occupying ability as the smaller particles are packed in the voids between the larger particles which can impact both bulk density and flowability (Tonon et al. 2008). According to the ANOVA mean values, SMPbased particles had the smaller mean size $(10.96 \mu \mathrm{m})$ whereas the addition of WPC and SC led to a significant increase of the $d_{\mathrm{v}, 50}$ values (12.03 and $12.37 \mu \mathrm{m}$, respectively). On the other hand, the presence of D-glucose also induced a reduction in the mean particle size $(10.68 \mu \mathrm{m})$ when compared to the systems without sugar or with added trehalose (12.42 and $12.24 \mu \mathrm{m}$, respectively). In previous studies it has been demonstrated that the elevation of the inlet temperature results in the formation of large microcapsule particles, whilst dehydration at lower heat transfer rates favors the production of fine powders due to partial collapse of the microparticles (Reineccius 2001). The effect of the ingredients on the viscosity of the spray drying aliquot can also modify the particles mean size, and thus high molecular weight materials that promote gelation, entangle with polysaccharides, or bind water can also increase the spray dried powders mean size (Tonon et al. 2008). The higher viscosities (data not shown) observed in the case of the SC and WPC containing drying media could explain the former results.

\section{Morphological Characterization}

In Fig. 2, images of the microcapsules microstructure in the absence (Fig. 2a) or presence of milk proteins (Fig. 2b-d) acquired using high resolution SEM are illustrated. Regardless the matrices composition, the microcapsules were characterized as having a spherical shape with concavities and surface deflations but with no evidence of cracks or fissures. The 'flat ball' effect has been also reported in previous studies and it is directly related with the conditions during spray drying (particularly with the heat penetration and water evaporation from the liquid droplet) and the chamber design (Barbosa-Cánovas et al. 2005). Fang et al. (2012) demonstrated that intermediate inlet temperatures are associated with partially collapsed matrices but also with good mechanical strength and dissolution properties of the
Fig. 1 Particle mean size distributions of powders produced with different milk proteins. Open diamond maltodextrin $15 \mathrm{DE}$, open circle maltodextrin $15 \mathrm{DE} / \mathrm{skim}$ milk powder (8:2), open square maltodextrin/whey protein concentrate $(8: 2)$, open triangle maltodextrin/sodium caseinate $(8: 2)$

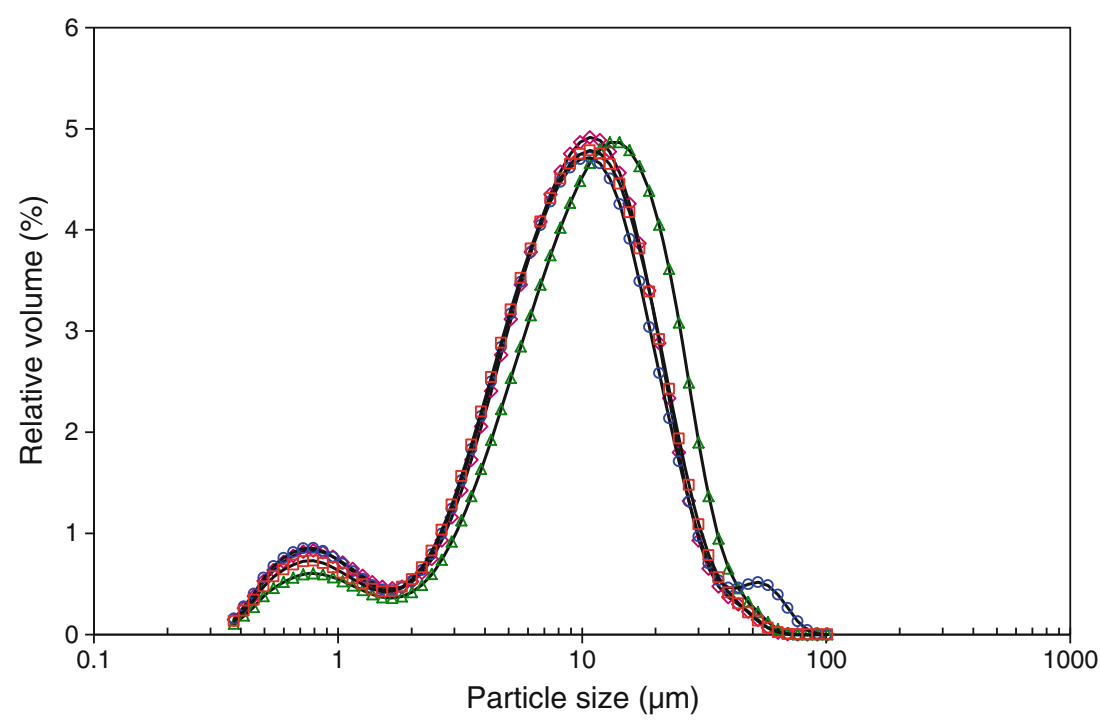


Fig. 2 SEM micrographs of spray dried microcapsules without (a) or with different (b-d) milk proteins: b skim milk powder, c whey protein concentrate, $\mathbf{d}$ sodium caseinate. Bar size $=20 \mu \mathrm{m}$
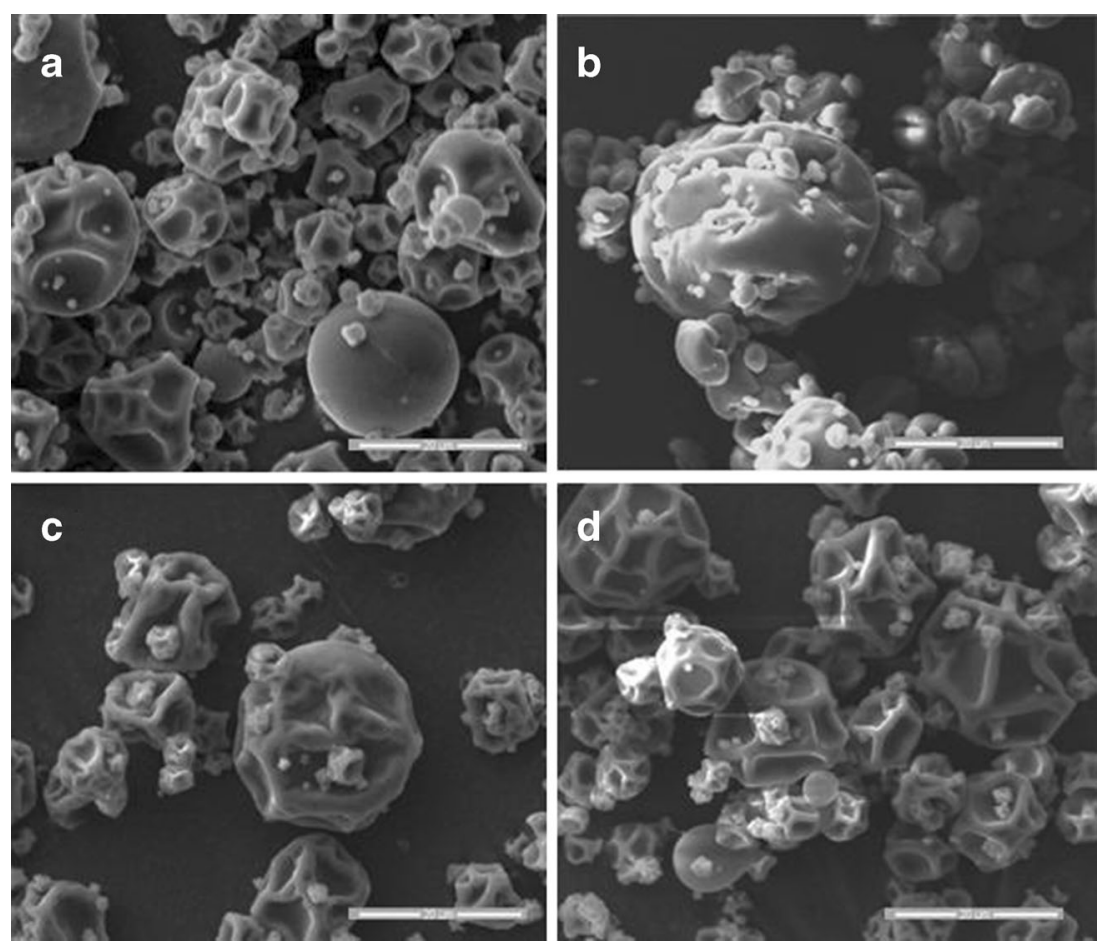

resultant powder. Considering the effect of milk protein on the morphological aspects of the microparticles, SC-based matrices exhibited the most deflated surface followed by WPC and SMP. Compared to the WPC-only systems, microcapsules with added D-glucose (Fig. 3a) or trehalose (Fig. 3b) did not reveal any apparent difference in terms of microstructure.

\section{Thermophysical Properties}

Glass transition phenomena related properties (onset and midpoint glass temperature) as calculated from the DSC thermographs are displayed in Table 3. Glass transition temperature $\left(T_{\mathrm{g}}\right)$ is of high importance for spray dried products as it is directly related with their physical (stickiness and caking) and structural (pores collapse, changes in texture and rehydration ability) stability and the occurrence of biochemical (lipid oxidation, enzymatic reaction-based texture or color changes) reactions upon storage (Karel et al.
1994; Barbosa-Cánovas et al. 2005). Moreover, in the case of anhydrobiotics, the establishment of amorphous rather than crystalline conformations has been reported as a critical factor for the control of the viability of biological systems (Passot et al. 2012). According to our results, the WPC and SMP-based systems were characterized by significantly lower $T_{\mathrm{g}}$ values $\left(99^{\circ} \mathrm{C}\right.$ and $74{ }^{\circ} \mathrm{C}$, respectively) compared to the control $\left(106^{\circ} \mathrm{C}\right)$ and $\mathrm{SC}\left(112^{\circ} \mathrm{C}\right)$ containing powders. The dependence of $\mathrm{T}_{\mathrm{g}}$ on matrix composition and residual moisture content can explain the former observations. The high lactose and water contents of the SMP containing powders will act as a plasticizer for MD, thereby depressing the $T_{\mathrm{g}}$ values when compared to WPC and SC. The presence of added sugars further induced the lowering of the glass transition temperature of the powders, D-glucose addition caused a more prominent depression of $T_{\mathrm{g}}$ values ranging from $74.3{ }^{\circ} \mathrm{C}$ to $49.4{ }^{\circ} \mathrm{C}$ for SMP, from $99.5{ }^{\circ} \mathrm{C}$ to $59.0^{\circ} \mathrm{C}$ for WPC and from $112{ }^{\circ} \mathrm{C}$ to $66.3{ }^{\circ} \mathrm{C}$ for SC-based microcapsules. Although sugars are generally considered as good
Fig. 3 SEM micrographs of whey protein concentrate-based microcapsules in the presence of D-glucose (a) or trehalose (b). Bar size $=20 \mu \mathrm{m}$
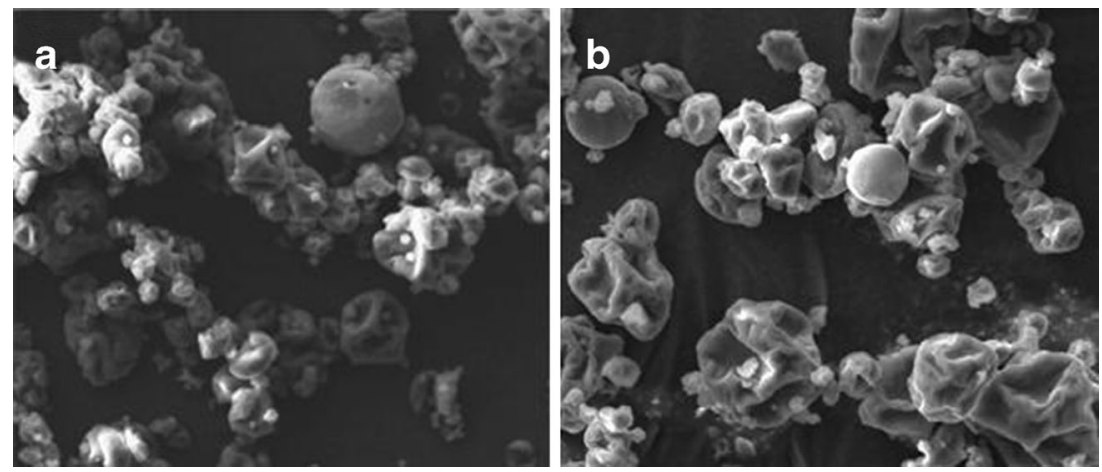
Table 3 Effect of the matrix wall composition on glass transition temperature $\left(T_{\mathrm{g}}\right)$ of the spray dried powders containing L. acidophilus NCIMB 701748

\begin{tabular}{lll}
\hline Spray drying medium & Onset $T_{\text {on }}\left({ }^{\circ} \mathrm{C}\right)$ & $T_{\mathrm{g}}$ midpoint $\left({ }^{\circ} \mathrm{C}\right)$ \\
\hline $\mathrm{MD}$ & $94.7 \pm 3.1^{\mathrm{g}}$ & $106.4 \pm 3.4^{\mathrm{g}}$ \\
$\mathrm{MD} / \mathrm{SMP}$ & $67.7 \pm 1.5^{\mathrm{e}}$ & $74.3 \pm 1.9^{\mathrm{e}}$ \\
$\mathrm{MD} / \mathrm{SMP} / \mathrm{G}$ & $35.3 \pm 0.2^{\mathrm{a}}$ & $49.4 \pm 0.0^{\mathrm{a}}$ \\
$\mathrm{MD} / \mathrm{SMP} / \mathrm{T}$ & $58.3 \pm 0.3^{\mathrm{d}}$ & $69.4 \pm 0.0^{\mathrm{d}}$ \\
$\mathrm{MD} / \mathrm{WPC}$ & $82.8 \pm 2.7^{\mathrm{f}}$ & $99.5 \pm 2.5^{\mathrm{f}}$ \\
$\mathrm{MD} / \mathrm{WPC} / \mathrm{G}$ & $40.2 \pm 1.7^{\mathrm{b}}$ & $59.0 \pm 1.7^{\mathrm{b}}$ \\
$\mathrm{MD} / \mathrm{WPC} / \mathrm{T}$ & $58.0 \pm 0.8^{\mathrm{d}}$ & $70.6 \pm 0.6^{\mathrm{de}}$ \\
$\mathrm{MD} / \mathrm{SC}$ & $96.0 \pm 2.0^{\mathrm{g}}$ & $111.7 \pm 2.6^{\mathrm{g}}$ \\
$\mathrm{MD} / \mathrm{SC} / \mathrm{G}$ & $46.5 \pm 0.8^{\mathrm{c}}$ & $66.3 \pm 1.2^{\mathrm{c}}$ \\
$\mathrm{MD} / \mathrm{SC} / \mathrm{T}$ & $55.3 \pm 0.9^{\mathrm{d}}$ & $72.9 \pm 0.5^{\mathrm{e}}$ \\
\hline
\end{tabular}

Different letters between rows indicate significant difference according to Duncan's mean post-hoc comparison test $(p<0.05)$

$M D$ maltodextrin $15 \mathrm{DE}, W P C$ whey protein concentrate, $S M P$ skim milk powder, $S C$ sodium caseinate, $G$ glucose, $T$ trehalose

plasticizers, trehalose acts in a different way to other disaccharides (such as sucrose or maltose) and is characterized by its peculiar physicochemical behavior, where in its pure form its $T_{\mathrm{g}}$ values are comparatively high (Sussich \& Cesàro 2000). This is due to the presence of symmetrical glucosidic residues and the absence of reducing groups in trehalose (Cesáro et al. 2007). Thus, the higher $T_{\mathrm{g}}$ values of protein-trehalose systems can be mainly attributed to trehalose's higher $T_{\mathrm{g}}$ value $\left(\sim 120{ }^{\circ} \mathrm{C}\right)$ compared to D-glucose $\left(\sim 31-38^{\circ} \mathrm{C}\right)$ which leads to more pronounced steric interactions with water molecules and reduced availability of water for the participation in biochemical or physical changes (Roos 1995).

\section{Color Measurements}

The color of protein-based spray dried powders is an important quality attribute. Color can be influenced by the structure of the powder, packing density, color of the spray drying carrier, and severity of the processing conditions, e.g., overheating caused by high inlet temperatures or long residence times in the drying chamber (Fritzen-Freire et al. 2012). According to Table 4, the SMP containing powders exhibited $L^{*}$ values similar to those of MD whereas WPC and SC containing samples had significantly $(p<0.05)$ lower $L^{*}$ values than SMP. Although no clear trends were revealed for the $a^{*}$ parameter as a function of the matrix composition, a negative value was obtained for all of the samples suggesting a tendency to blue color hues. Similar results have been also reported by Fritzen-Freire et al. (2012) in reconstituted milk powder-based probiotic microcapsules. All samples were characterized by positive $b^{*}$ values indicating yellowish hue color. More specifically, the WPC containing powders were determined as the most yellow followed by SMP and SC. Contrary to milk proteins the colorless sugars had no significant $(p>0.05)$ impact on all tested color attributes.

The total color difference values $\left(\Delta E^{*}\right)$ ranged from 0.89 to 3.15 for SMP-trehalose and WPC containing systems, respectively. Martinez-Cervera et al. (2011) stated that $\Delta E^{*}$ values less than 3 cannot be visually perceived by humans, and consequently with the exception of MDWPC systems, the rest of the formulations are expected to be equally evaluated in terms of color.

Survival Rates of the Bacteria and Cyclone Separation Yield During Spray Drying

Considering that the operating spray drying conditions can critically impact the viability of thermo-sensitive probiotic strains such as L. acidophilus, the optimum inlet temperature and feeding rate conditions were pre-selected in order to minimize the sub-lethal injuries of the bacterial cells throughout the process. Generally, an increase of inlet temperature from $120{ }^{\circ} \mathrm{C}$ to $160{ }^{\circ} \mathrm{C}$ at constant feeding rate conditions induced 5- to 10-fold decrease of the viable counts of L. acidophilus (data not shown). To evaluate the impact of the spray drying carrier medium on the viability of L. acidophilus during spray drying, results were generated under optimized processing conditions for all samples. The survival rates of $L$. acidophilus were significantly $(p<0.001)$ affected by the composition of the carrier (Table 5). The lowest viabilities were observed for the control $(0.44 \%)$ sample (MD) and SC (0.88-6.04\%) systems, whereas the highest viability was recorded in the WPC containing samples (12-69.9\%). A full explanation of the enhanced stability offered by milk proteins is not currently available (Fu \& Chen 2011). Generally, SMP has been reported as a very effective protectant on cell viability during spray drying a function that has been attributed to lactose; lactose has the ability to interact with cell membranes retaining their structural integrity (Corcoran et al. 2004). Moreover, as in the case of the non-reducing disaccharides, e.g., trehalose or sucrose, lactose can depress the gel to liquid crystalline state transition temperature of cell membrane's lipid bilayer aiding cells to retain their native structural conformation (Fu \& Chen 2011). This mechanism could also be extended to other milk protein formulations with similar compositional elements such as whey protein concentrates or isolates, milk protein concentrates or caseinates. According to the experimental values of glass transition temperature $\left(T_{\mathrm{g}}\right)$ (Table 3), a significant depression, although at a lesser extent compared to sugars, was observed by the partial replacement of MD by SMP or WPC $\left(T_{\mathrm{g}}=74.3^{\circ} \mathrm{C}\right.$ and $99.5^{\circ} \mathrm{C}$, respectively) whilst no significant differences between the glass transition temperatures of the MD or SC containing systems were observed (Table 3). Moreover, whey proteins are well 
Table 4 Effect of the matrix wall composition on color characteristics of the spray dried powders containing L. acidophilus NCIMB 701748

Different letters between rows indicate significant difference according to Duncan's mean post-hoc comparison test $(p<$ $0.05)$

$M D$ maltodextrin $15 \mathrm{DE}, W P C$ whey protein concentrate, $S M P$ skim milk powder, $S C$ sodium caseinate, $G$ glucose, $T$ trehalose

\begin{tabular}{lllll}
\hline Spray drying medium & $L^{*}$ & $a^{*}$ & $b^{*}$ & Total color $\left(\Delta E^{*}\right)$ \\
\hline $\mathrm{MD}$ & $97.60 \pm 0.00^{\mathrm{f}}$ & $-0.005 \pm 0.012^{\mathrm{g}}$ & $1.34 \pm 0.00^{\mathrm{a}}$ & \\
$\mathrm{MD} / \mathrm{SMP}$ & $96.93 \pm 0.00^{\mathrm{d}}$ & $-0.235 \pm 0.014^{\mathrm{b}}$ & $3.33 \pm 0.43^{\mathrm{f}}$ & $2.11 \pm 0.42^{\mathrm{d}}$ \\
$\mathrm{MD} / \mathrm{SMP} / \mathrm{G}$ & $97.51 \pm 0.14^{\mathrm{f}}$ & $-0.108 \pm 0.015^{\mathrm{f}}$ & $2.62 \pm 0.01^{\mathrm{e}}$ & $1.29 \pm 0.13^{\mathrm{b}}$ \\
$\mathrm{MD} / \mathrm{SMP} / \mathrm{T}$ & $97.16 \pm 0.01^{\mathrm{e}}$ & $-0.110 \pm 0.000^{\mathrm{f}}$ & $2.11 \pm 0.00^{\mathrm{d}}$ & $0.89 \pm 0.01^{\mathrm{a}}$ \\
$\mathrm{MD} / \mathrm{WPC}$ & $96.27 \pm 0.06^{\mathrm{c}}$ & $-0.265 \pm 0.013^{\mathrm{a}}$ & $4.18 \pm 0.08^{\mathrm{g}}$ & $3.15 \pm 0.09^{\mathrm{f}}$ \\
$\mathrm{MD} / \mathrm{WPC} / \mathrm{G}$ & $95.59 \pm 0.07^{\mathrm{a}}$ & $-0.210 \pm 0.006^{\mathrm{c}}$ & $2.76 \pm 0.07^{\mathrm{e}}$ & $2.47 \pm 0.09^{\mathrm{d}}$ \\
$\mathrm{MD} / \mathrm{WPC} / \mathrm{T}$ & $96.02 \pm 0.16^{\mathrm{b}}$ & $-0.110 \pm 0.028^{\mathrm{ef}}$ & $3.16 \pm 0.09^{\mathrm{f}}$ & $2.41 \pm 0.18^{\mathrm{d}}$ \\
$\mathrm{MD} / \mathrm{SC}$ & $95.72 \pm 0.06^{\mathrm{a}}$ & $-0.098 \pm 0.025^{\mathrm{f}}$ & $2.14 \pm 0.11^{\mathrm{d}}$ & $2.05 \pm 0.12^{\mathrm{c}}$ \\
$\mathrm{MD} / \mathrm{SC} / \mathrm{G}$ & $95.74 \pm 0.11^{\mathrm{a}}$ & $-0.153 \pm 0.015^{\mathrm{d}}$ & $1.90 \pm 0.04^{\mathrm{c}}$ & $1.95 \pm 0.11^{\mathrm{c}}$ \\
$\mathrm{MD} / \mathrm{SC} / \mathrm{T}$ & $95.71 \pm 0.00^{\mathrm{a}}$ & $-0.125 \pm 0.004^{\mathrm{e}}$ & $1.65 \pm 0.00^{\mathrm{b}}$ & $1.91 \pm 0.00^{\mathrm{c}}$ \\
\hline
\end{tabular}

known for their ability to release sulfur containing amino acids when they are subjected to heat treatments which can act as strong oxygen scavengers thereby lowering the redox potential (Dave \& Shah 1998; Antunes et al. 2005) and consequently inhibiting the oxidation of the membrane lipid bilayer, which can otherwise be lethal (Garre et al. 2010). Another mechanism that potentially could also affect the survival rate of L. acidophilus through the spray drying process is the ability of proteins, particularly of the whey proteins, to bind water through hydrogen bonds (Kinsella 1984) which can protect cellular membranes from dehydration in a similar manner to other carbohydrate-based thermoprotectants. From our data, it seems that a synergism between these mechanisms could explain the demonstrated improvement of the cells thermotolerance upon dehydration.

Of the sugars, D-glucose conferred significant thermoprotective effects leading to a $59.3 \%$ to $131 \%$ increase in L. acidophilus viability in both SC and SMP systems

Table 5 Viability of L. acidophilus NCIMB 701748 after the spray drying and yield ( $\%$ on a dry basis) of the spray drying process as function of the composition of the spray drying medium

\begin{tabular}{lll}
\hline Spray drying medium & Viability (\%) & Cyclone recovery (\%) \\
\hline $\mathrm{MD}$ & $0.44 \pm 0.03^{\mathrm{a}}$ & $66.7 \pm 3.1^{\mathrm{cd}}$ \\
$\mathrm{MD} / \mathrm{SMP}$ & $19.2 \pm 3.7^{\mathrm{f}}$ & $59.7 \pm 0.1^{\mathrm{b}}$ \\
$\mathrm{MD} / \mathrm{SMP} / \mathrm{G}$ & $30.6 \pm 3.8^{\mathrm{g}}$ & $63.2 \pm 0.6^{\mathrm{c}}$ \\
$\mathrm{MD} / \mathrm{SMP} / \mathrm{T}$ & $59.2 \pm 2.4^{\mathrm{h}}$ & $59.7 \pm 2.0^{\mathrm{b}}$ \\
$\mathrm{MD} / \mathrm{WPC}$ & $64.0 \pm 1.8^{\mathrm{hi}}$ & $70.3 \pm 0.2^{\mathrm{d}}$ \\
$\mathrm{MD} / \mathrm{WPC} / \mathrm{G}$ & $69.9 \pm 4.3^{\mathrm{i}}$ & $68.3 \pm 0.8^{\mathrm{d}}$ \\
$\mathrm{MD} / \mathrm{WPC} / \mathrm{T}$ & $12.4 \pm 1.7^{\mathrm{e}}$ & $58.1 \pm 0.1^{\mathrm{b}}$ \\
$\mathrm{MD} / \mathrm{SC}$ & $2.61 \pm 0.06^{\mathrm{c}}$ & $73.1 \pm 1.2^{\mathrm{e}}$ \\
$\mathrm{MD} / \mathrm{SC} / \mathrm{G}$ & $6.04 \pm 1.62^{\mathrm{d}}$ & $73.5 \pm 1.1^{\mathrm{e}}$ \\
$\mathrm{MD} / \mathrm{SC} / \mathrm{T}$ & $0.89 \pm 0.00^{\mathrm{b}}$ & $53.0 \pm 0.2^{\mathrm{a}}$ \\
\hline
\end{tabular}

Different letters between rows indicate significant difference according to Duncan's mean post-hoc comparison test $(p<0.05)$

$M D$ maltodextrin $15 \mathrm{DE}, W P C$ whey protein concentrate, $S M P$ skim milk powder, $S C$ sodium caseinate, $G$ glucose, $T$ trehalose (there was an increase in mean viability in WPC, although this was not statistically significant at $p<0.05)$; trehalose significantly increased cell viability in the case of the SMP-based formulations (2-fold) which supports the results of Sunny-Roberts and Knorr (2009), although in WPC and SC systems increased viability loss during spray drying was observed (although all systems containing sugars offered enhanced stability over the MD system. The use of sugars and polyols as thermoprotective agents of biological systems subjected to convective thermal processes is mainly associated with their ability to protect the structural integrity of the cells by replacing water at the membranes interface and reducing damage to the cells membrane lipid bilayer during dehydration (Castro et al. 1997). The protective role of trehalose and D-glucose has been also previously reported in the case of $L$. rhamnosus, $L$. plantarum and L. paracasei (Ying et al. 2012; Lapsiri et al. 2012; Sunny-Roberts \& Knorr 2009; Semyonov et al. 2011; Li et al. 2008).

Modification of the spray drying carrier had also a significant impact on the powder recovery in the cyclone as displayed in Table 5. Thus, the use of SC or WPC can lead to a remarkable improvement of the product recovery rate, i.e., $73.1 \%$ and $70.3 \%$, respectively, which is substantially higher than that achieved in the case of MD. The presence of D-glucose did not alter significantly the yield of the spray drying process in contrast to the addition of trehalose which resulted in a steep decrease of the cyclone recovery particularly in the case of SC containing powders.

\section{Survival Rates of the Bacteria During Storage}

The viability of spray dried probiotics formulations over storage was monitored at 1-week intervals for the first month and after 12 weeks of storage, the results are detailed in Fig. 4. The dependency of L. acidophilus survival rates on storage temperature $\left(4^{\circ} \mathrm{C}, 25^{\circ} \mathrm{C}\right.$ and $\left.35^{\circ} \mathrm{C}\right)$ was also determined. The rate 

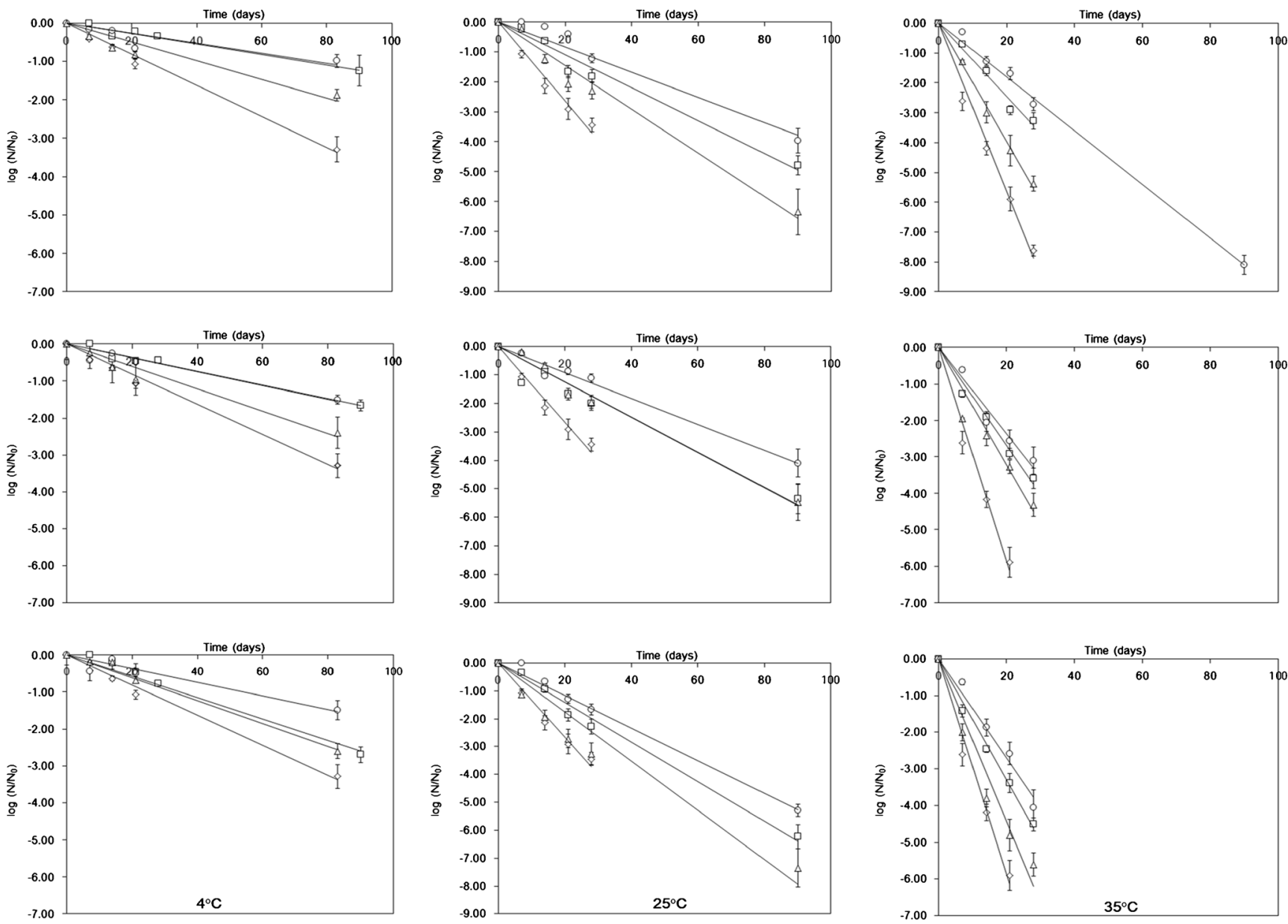

Fig. 4 Survival rates of microencapsulated L. acidophilus NCIMB 701748 as function of milk protein (MP) type and storage temperature. caseinate, empty diamond $\mathrm{MD}$, empty circle $\mathrm{MD} / \mathrm{MP}$, empty square $\mathrm{MD} / \mathrm{MP} / \mathrm{G}$, empty triangle $\mathrm{MD} / \mathrm{MP} / \mathrm{T}$

a-c Skim milk powder, $\mathbf{d}-\mathbf{f}$ whey protein concentrate, $\mathbf{g}-\mathbf{i}$ sodium

constants of the L. acidophilus inactivation upon storage was calculated according to a first order kinetics model, as has been successfully previously used by other researchers (Ananta et al. 2005; Heidebach et al. 2010; Ying et al. 2010). The resultant first order model fitted well $\left(R^{2}=0.815-0.99\right)$ to our data particularly at higher storage temperatures $\left(25^{\circ} \mathrm{C}\right.$ and $\left.35^{\circ} \mathrm{C}\right)$.
In samples stored at $4{ }^{\circ} \mathrm{C}$ for 7 days, growth occurred leading to a 0.13 to $0.46 \log \mathrm{CFU} / \mathrm{g}$ increase of the L. acidophilus viable counts (this was dependent on the composition of the microcapsules). After the initial 7 days, a gradual decrease in viability took place, with a reduction from 0.99 to $3.29 \mathrm{log}$ $\mathrm{CFU} / \mathrm{g}$, for the SMP-D-glucose and MD systems, respectively.
Table 6 Effect of the matrix wall composition on inactivation rate $\left(\right.$ day $\left.^{-1}\right)$ of L. acidophilus NCIMB 701748

Different letter between rows indicate significant difference according to Duncan's mean post-hoc comparison test $(p<0.05)$

$M D$ maltodextrin $15 \mathrm{DE}, W P C$ whey protein concentrate, SMP skim milk powder, $S C$ sodium caseinate, $G$ glucose, $T$ trehalose

\begin{tabular}{llll}
\hline Spray drying medium & $k_{4^{\circ} \mathrm{C}}\left(R^{2}\right)$ & $k_{25^{\circ} \mathrm{C}}\left(R^{2}\right)$ & $k_{35^{\circ} \mathrm{C}}\left(R^{2}\right)$ \\
\hline $\mathrm{MD}$ & $0.041(0.987)$ & $0.133(0.976)$ & $0.281(0.984)$ \\
$\mathrm{MD} / \mathrm{SMP}$ & $0.015(0.938)$ & $0.055(0.973)$ & $0.123(0.978)$ \\
$\mathrm{MD} / \mathrm{SMP} / \mathrm{G}$ & $0.013(0.815)$ & $0.042(0.956)$ & $0.090(0.996)$ \\
$\mathrm{MD} / \mathrm{SMP} / \mathrm{T}$ & $0.024(0.882)$ & $0.072(0.980)$ & $0.198(0.994)$ \\
$\mathrm{MD} / \mathrm{WPC}$ & $0.021(0.941)$ & $0.062(0.944)$ & $0.134(0.981)$ \\
$\mathrm{MD} / \mathrm{WPC} / \mathrm{G}$ & $0.019(0.923)$ & $0.045(0.982)$ & $0.118(0.963)$ \\
$\mathrm{MD} / \mathrm{WPC} / \mathrm{T}$ & $0.030(0.956)$ & $0.062(0.986)$ & $0.161(0.929)$ \\
$\mathrm{MD} / \mathrm{SC}$ & $0.033(0.998)$ & $0.100(0.956)$ & $0.165(0.991)$ \\
$\mathrm{MD} / \mathrm{SC} / \mathrm{G}$ & $0.018(0.906)$ & $0.066(0.993)$ & $0.135(0.980)$ \\
$\mathrm{MD} / \mathrm{SC} / \mathrm{T}$ & $0.030(0.985)$ & $0.088(0.941)$ & $0.221(0.881)$ \\
\hline
\end{tabular}


Table 7 Effect of the matrix wall composition on activation energy $E_{\mathrm{a}}$ (kJ/mol) of L. acidophilus NCIMB 701748

\begin{tabular}{llll}
\hline Spray drying medium & $\log k_{0}$ & $E_{\mathrm{a}}(\mathrm{kJ} / \mathrm{mol})$ & $R^{2}$ \\
\hline $\mathrm{MD}$ & 6.71 & 43.4 & 0.990 \\
$\mathrm{MD} / \mathrm{SMP}$ & 7.05 & 47.1 & 0.991 \\
$\mathrm{MD} / \mathrm{SMP} / \mathrm{G}$ & 6.25 & 43.2 & 0.989 \\
$\mathrm{MD} / \mathrm{SMP} / \mathrm{T}$ & 7.05 & 46.1 & 0.960 \\
$\mathrm{MD} / \mathrm{WPC}$ & 5.95 & 40.5 & 0.963 \\
$\mathrm{MD} / \mathrm{WPC} / \mathrm{G}$ & 5.65 & 39.4 & 0.964 \\
$\mathrm{MD} / \mathrm{WPC} / \mathrm{T}$ & 5.21 & 35.8 & 0.953 \\
$\mathrm{MD} / \mathrm{SC}$ & 5.44 & 36.7 & 0.999 \\
$\mathrm{MD} / \mathrm{SC} / \mathrm{G}$ & 6.82 & 45.4 & 0.996 \\
$\mathrm{MD} / \mathrm{SC} / \mathrm{T}$ & 7.48 & 48.3 & 0.981 \\
\hline
\end{tabular}

$M D$ maltodextrin $15 \mathrm{DE}, W P C$ whey protein concentrate, $S M P$ skim milk powder, $S C$ sodium caseinate, $G$ glucose, $T$ trehalose

The inactivation rates of the bacteria at $4{ }^{\circ} \mathrm{C}$ were calculated by subtracting the growth time and correcting the initial number of viable counts from the model:

$\log \mathrm{N}=\log \mathrm{N}_{0}^{\prime}+\mathrm{k}_{\mathrm{T}}(\mathrm{t}-7)$

where $N_{0}{ }^{\prime}$, represents the corrected initial number of the viable bacteria and $\mathrm{N}$ the number of viable bacteria after a specific time of storage (in $\mathrm{CFU} / \mathrm{g}$ ), $t$ is the storage time (in day), and $k_{\mathrm{T}}$ is the inactivation rate constant at $T$ temperature $\left(\right.$ day $\left.^{-1}\right)$.

Milk protein addition improved the survival rates of $L$. acidophilus at $4{ }^{\circ} \mathrm{C}$ in the order $\mathrm{SMP}>\mathrm{WPC}>\mathrm{SC}$ (Table 6). The addition of D-glucose and trehalose had minimal effect on the viability of $L$. acidophilus upon storage (no change, slight reduction in viability upon storage, respectively). At $35^{\circ} \mathrm{C}$ L. acidophilus viability loss was more significant and there was a greater impact of changes in the matrix composition on viability. There was a 3 -fold and 7 -fold reduction in survival rates at $25^{\circ} \mathrm{C}$ and $35^{\circ} \mathrm{C}$, respectively, compared to those at $4{ }^{\circ} \mathrm{C}$, with $\mathrm{MD}$ and $\mathrm{SC}$-based microcapsules being the most susceptible to storage related loss (Table 6). The presence of SMP or WPC improved the performance of the microcapsules as well as the D-glucose supplementation. Fitting the inactivation rate constants data to the Arrhenius model, the activation energies $E_{\mathrm{A}}$ for $L$. acidophilus were calculated (Table 7). $E_{\mathrm{A}}$ is an indication of temperature dependency of the inactivation rates, and in that aspect they can be used to estimate the impact of temperature changes on the viability of $L$. acidophilus as might be experienced during anhydrobiotics processing or storage (Lapsiri et al. 2012). The $E_{\mathrm{A}}$ for the control was $43.4 \mathrm{~kJ} / \mathrm{mol} \mathrm{K}$. This is greater than that for WPC $(35.8-40.5 \mathrm{~kJ} / \mathrm{mol} \mathrm{K})$ containing microcapsules and lower than that of the SMP systems $(43.2-47.1 \mathrm{~kJ} / \mathrm{mol} \mathrm{K})$, indicating that SMP-based powders are most susceptible to thermal damage, and that WPC are the most thermally stable to temperature changes which would results in enhanced viability, particularly under common handling and storage conditions where temperature fluctuations might be expected.

Practically, retaining probiotic viability is challenging due the combination of both endogenous and exogenous factors contributing to cell death. Generally, it is accepted that factors such as residual moisture; storage temperature; the growth state (exponential or stationary) of the culture; presence of growth stimulants or oxygen scavengers, together with the physical state (formation of glassy or rubbery structures) of the microcapsules are critical at influencing the storage stability of probiotic bacteria (Fu \& Chen 2011; Gardiner et al. 2000; Heidebach et al. 2010; Santivarangkna et al. 2011; Ying et al. 2012; Ananta et al. 2005; Corcoran et al. 2004). To ensure that L. acidophilus was found at the stationary growth state, the bacteria were allowed to grow for at least $48 \mathrm{~h}$ before harvesting and thus, the heat induced injuries due to growth state are expected to be quite low (Corcoran et al. 2004). In addition, the prevention of heat injuries during drying has been reported to be very important for the establishment of high post processing survival rates of the bacteria (Gardiner et al. 2000). Indeed, the viability of $L$. acidophilus during spray drying was found to be significantly correlated with the inactivation rates of the SMP and WPC containing powders at $25^{\circ} \mathrm{C}$ and $35{ }^{\circ} \mathrm{C}(-0.78$ and -0.84 , respectively; $p<0.05)$. Similarly, in the case of MD- and SCbased systems the high heat and osmotic stress injuries occurred during spray drying did not favor the performance of $L$. acidophilus throughout storage (both formulations were characterized by high k-rate values).

On the other hand, considering that all the systems were stored under controlled relative humidity conditions in sealed glass containers the residual moisture content and physical state of the systems will be expected to be key factors in the viability of $L$. acidophilus upon storage. No significant correlations $(p>0.05)$ were observed between the $a_{\mathrm{w}}$, moisture or $T_{\mathrm{g}}$ values with $k$ rates for each temperature this is probably because all of the systems are already found in the glassy state, and thus the impact of the physical parameters is therefore minimized. Our results suggest that within the tested moisture levels $(1.6-4 \% \mathrm{w} / \mathrm{w})$ the individual functionality of the matrix components has the greatest impact on the viability of the probiotics and is more important than the physical state of the system. For instance, the release of free radical scavenging peptides from whey proteins can stimulate the growth of bacteria by impeding lipid auto-oxidation which might be more impactful than moving the systems further away from the WLF reaction governed state (increasing the $T-T_{\mathrm{g}}$ value). Semyonov et al. (2011) reported a better stability of $L$. plantarum in 5DE compared to 19DE MD despite differences in $a_{\mathrm{w}}$ (higher $a_{\mathrm{w}}$ values of the former). Similarly, SunnyRoberts and Knorr $(2009,2011)$ showed that the substitution of trehalose by monosodium glutamate (MSG) seemed to 
increase remarkably the survival rates of L. rhamnosus GG when compared directly to trehalose (despite the alterations of $T_{\mathrm{g}}$ values) whereas Rodrigues et al. (2011) reported that the detrimental effects of relative humidity and oxygen presence are mainly strain dependent and the presence of $\mathrm{HCl}$ cysteine as oxygen scavenger could improve the viability of $L$. acidophilus.

\section{Conclusions}

In this work, the thermoprotective role of the milk proteins as partial matrix components of L. acidophilus spray dried microcapsules was evaluated for their ability to enhance microbial stability and modify the powders functional properties. The ratio of casein to whey proteins and the lactose content of milk proteins are shown to be key factors in the exhibited viability of $L$. acidophilus through the drying process. SMP due to its high lactose content and WPC, which has the ability to form lipid peroxidation scavengers of protein origin were the most efficient thermoprotective agents. Storage of the probiotic powders at different temperatures revealed that storage time and temperature dependency of the inactivation rates of $L$. acidophilus can be dramatically changed as a function of protein choice. Protein ingredients that promote high survival rates as a function of storage time can show increased microbial instability as storage temperature is changed. The addition of sugars can further improve the thermoprotective action of proteins, presumably due to their ability to depress the glass transition temperature of the system. The use of MD-SMP or WPC-D-glucose as carriers was shown to be a good strategy for the production of high viability microencapsulated $L$. acidophilus, although there were minor compromises in some technological powder characteristics such as water activity, residual water content, hygroscopicity and color attributes.

Acknowledgements The authors gratefully acknowledge Mrs. Val Street, Dr. Phil Richards for scientific advice relating to DSC measurements and microbiological testing respectively, and Eminate Ltd. for technical assistance. Moreover, Cargill Ltd. (Manchester, UK), Arla A/ S (Viby, Denmark) and Hayashibara Ltd. (Tokyo, Japan) are also acknowledged for supplying the dry materials used in the present work.

Open Access This article is distributed under the terms of the Creative Commons Attribution License which permits any use, distribution, and reproduction in any medium, provided the original author(s) and the source are credited.

\section{References}

Ananta, E., Volkert, M., \& Knorr, D. (2005). Cellular injuries and storage stability of spray dried Lactobacillus rhamnosus GG. International Dairy Journal, 15, 399-409.
Antunes, A. E. C., Cazetto, T. F., \& Bolini, H. M. A. (2005). Viability of probiotic micro-organisms during storage, postacidification and sensory analysis of fat-free yogurts with added whey protein concentrate. International Journal of Dairy Technology, 58(3), $169-173$.

Barbosa-Cánovas, G. V., Ortega-Rivas, E., Juliano, P., \& Yan, H. (2005). Food Powders: Physical properties, processing and functionality. New York, USA: Kluwer Academic.

Behboudi-Jobbedhar, S., Soukoulis, C., Yonekura, L., \& Fisk, I.D. (2013) Optimisation of spray drying conditions for the production of maximally viable L. acidophilus NCIMB 701748. Drying Technology: An International Journal, doi:10.1080/07373937. 2013.788509.

Burgain, J., Gaiani, C., Linder, M., \& Scher, J. (2011). Encapsulation of probiotic living cells: from laboratory scale to industrial applications. Journal of Food Engineering, 104, 467-483.

Castro, H. P., Teixeira, P. M., \& Kirby, R. (1997). Evidence of membrane damage in Lactobacillus bulgaricus following freeze drying. Journal of Applied Microbiology, 82(1), 87-94.

Cesáro, A., De Giacomo, O., \& Sussich, F. (2007). Water interplay in trehalose polymorphism. Food Chemistry, 106, 1318-1328.

Champagne, C. P., Ross, R. P., Saarela, M., Hansen, K. F., \& Charalampopoulos, D. (2011). Recommendations for the viability assessment of probiotics as concentrated cultures and in food matrices. International Journal of Food Microbiology, 149, 185-193.

Cho, S. S., \& Finocchiaro, T. E. (2010). Handbook of prebiotics and probiotics: Health benefits and food applications. Boca Raton, FL, USA: CRC Press - Taylor and Francis group.

Corcoran, B. M., Ross, R. P., Fitzgerald, G. F., \& Stanton, C. (2004). Comparative survival of probiotic lactobacilli spray-dried in the presence of prebiotic substances. Journal of Applied Microbiology, 96, 1024-1039.

Corcoran, B. M., Stanton, C., Fitzgerald, G., \& Ross, R. P. (2008). Life under stress: the probiotic stress response and how it may be manipulated. Current Pharmaceutical Design, 14, 1382-1399.

Cruz, A. G., Antunes, A. E. C., Sousa, A. L. O. P., Faria, J. A. F., \& Saad, S. M. I. (2009). Ice cream as probiotic food carrier. Food Research International, 42(9), 1233-1239.

Dave, R. I., \& Shah, N. P. (1998). Ingredient supplementation effects on viability of probiotic bacteria in yogurt. Journal of Dairy Science, 81, 2804-2816.

De Castro-Cislaghi, F. P., Silva, C. D. R. E., Fritzen-Freire, C. B., Lorenz, J. G., \& Sant'Anna, E. S. (2012). Bifidobacterium Bb-12 microencapsulated by spray drying with whey: survival under simulated gastrointestinal conditions, tolerance to $\mathrm{NaCl}$ and viability during storage. Journal of Food Engineering, 113, 186-193.

Dommels, Y. E. M., Kemperman, R. A., Zebregs, Y. E. M. P., Draaisma, R. B. M., Jol, A., Wolvers, D. A. W., et al. (2009). Survival of Lactobacillus reuteri DSM 17938 and Lactobacillus rhamnosus GG in the human gastrointestinal tract with daily consumption of a low-fat probiotic spread. Applied and Environmental Microbiology, 75, 6198-6204.

Fang, Y., Rogers, S., Selomulya, C., \& Chen, X. D. (2012). Functionality of milk protein concentrate: effect of spray drying temperature. Biochemical Engineering Journal, 62, 101-105.

FAO/WHO. (2006). Probiotics in food. Health and nutritional properties and guidelines for evaluation. Rome, Italy: FAO Food and Nutrition Paper No. 85.

Fritzen-Freire, C. B., Prudencio, E. S., Amboni, R. D. M. C., Pinto, S. S., Negrao-Murakami, A. N., \& Murakami, F. S. (2012). Microencapsulation of bifidobacteria by spray drying in the presence of prebiotics. Food Research International, 45, 306-312.

Fu, N., \& Chen, X. D. (2011). Towards a maximal cell survival in convective thermal drying processes. Food Research International, 44, 1127-1149. 
Gardiner, G. E., O’Sullivan, E., Kelly, J., Auty, M. A. E., Fitzgerald, G. F., Collins, J. K., et al. (2000). Comparative survival rates of humanderived probiotic Lactobacillus paracasei and L. salivarius strains during heat treatment and spray drying. Applied and Environmental Microbiology, 66, 2605-2615.

Garre, E., Raginel, F., Palacios, A., Julien, A., \& Matallana, E. (2010). Oxidative stress responses and lipid peroxidation damage are induced during dehydration in the production of dry active wine yeasts. International Journal of Food Microbiology, 136, 295303.

Ghandi, A., Powell, I., Chen, X. D., \& Adhikari, B. (2012). Drying kinetics and survival studies of dairy bacteria in convective air drying environment using single droplet drying. Journal of Food Engineering, 110(3), 405-417.

Gharsallaoui, A., Roudaut, G., Chambin, O., Voilley, A., \& Saurel, R. (2007). Applications of spray-drying in microencapsulation of food ingredients: an overview. Food Research International, 40(9), 1107-1121.

Heidebach, T., Först, P., \& Kulozik, U. (2009). Transglutaminaseinduced caseinate gelation for the microencapsulation of probiotic cells. International Dairy Journal, 19, 77-84.

Heidebach, T., Först, P., \& Kulozik, U. (2010). Influence of casein-based microencapsulation on freeze-drying and storage of probiotic cells. Journal of Food Engineering, 98, 309319.

Jayasundera, M., Adhikari, B., Aldred, P., \& Ghandi, A. (2009). Surface modification of spray dried food and emulsion powders with surface-active proteins: a review. Journal of Food Engineering, 93, 266-277.

Karel, M., Anglea, S., Buera, P., Karmas, R., Levi, G., \& Roos, Y. (1994). Stability-related transitions of amorphous foods. Thermochimica Acta, 246, 249-269.

Kinsella, J. F. (1984). Milk proteins: physicochemical and functional properties. Critical Reviews in Food Science and Nutrition, 21(3), 197-262.

Lapsiri, W., Bhandari, B., \& Wanchaitanawong, P. (2012). Viability of Lactobacillus plantarum TISTR 2075 in different protectants during spray drying and storage. Drying Technology: An International Journal, 30, 1407-1412.

Li, X. Y., Chen, X. G., Liu, C. S., Peng, H. N., \& Cha, D. S. (2008). Effect of trehalose and drying process on the survival of encapsulated Lactobacillus casei ATCC 393. Drying Technology: An International Journal, 26, 895-901.

Malmo, C., La Storia, A., \& Mauriello, G. (2011). Microencapsulation of Lactobacillus reuteri DSM 17938 cells coated in alginate beads with chitosan by spray drying to use as a probiotic cell in a chocolate soufflé. Food and Bioprocess Technology. doi:10.1007/s11947-0110755-8.

Mantzouridou, F., Spanou, A., \& Kiosseoglou, V. (2012). An inulinbased dressing emulsion as a potential probiotic food carrier. Food Research International, 46(1), 260-269.

Martinez-Cervera, S., Salvador, A., Muguerza, B., Moulay, L., \& Fizman, S. M. (2011). Cocoa fibre and its application as a fat replacer in chocolate muffins. LWT- Food Science and Technology, 44, 729-736.

O'Brien-Nabors, L. (2012). Alternative sweeteners. Boca Raton, USA: CRC Press.

Passot, S., Cenard, S., Douania, I., Tréléa, I. C., \& Fonseca, F. (2012). Critical water activity and amorphous state for optimal preservation of lyophilized lactic acid bacteria. Food Chemistry, 132, 1699-1705.

Pérez-Chabela, M. L., Lara-Labastida, R., Rodriguez-Huezo, E., \& Totosaus, A. (2012). Effect of spray drying encapsulation of thermotolerant lactic acid bacteria on meat batters properties. Food and Bioprocess Technology. doi:10.1007/s11947-012$0865-\mathrm{y}$.
Pinto, S. S., Fritzen-Freire, C. B., Muñoz, I. B., Barreto, P. L. M., Prudêncio, E. S., \& Amboni, R. D. M. C. (2012). Effects of the addition of microencapsulated Bifidobacterium BB-12 on the properties of frozen yogurt. Journal of Food Engineering, $111(4), 563-569$.

Reddy, K. B. P. K., Madhu, A. N., \& Prupella, S. G. (2009). Comparative survival and evaluation of functional properties of spray dried lactic acid bacteria. International Journal of Dairy Technology, 62, 240-248.

Reineccius, G. A. (2001). Multiple-core encapsulation - the spray drying of food ingredients. In P. Vilstrup (Ed.), Microencapsulation of food ingredients (pp. 151-185). Surrey: Leatherhead Publishing.

Rodrigues, D., Sousa, S., Rocha-Santos, T., Silva, J. P., Sousa Lobo, J. M., Costa, P., et al. (2011). Influence of L-cysteine, oxygen and relative humidity upon survival throughout storage of probiotic bacteria in whey protein-based microcapsules. International Dairy Journal, 21, 869-876.

Rodrigues, D., Sousa, S., Gomes, A. M., Pintado, M. M., Silva, J. P., Costa, P., et al. (2012). Stability of Lactobacillus paracasei as free cells or encapsulated in alginate-based microcapsules in low $\mathrm{pH}$ fruit juices. Food and Bioprocess Technology, 5(7), 27482757.

Roos, Y. H. (1995). Phase transitions in foods. California, USA: Academic Press.

Saad, N., Delattre, C., Urdaci, M., Schmitter, J. M., \& Bressollier, P. (2013). An overview of the last advances in probiotic and prebiotic field. LWT- Food Science and Technology, 50, 116.

Saarela, M., Virkajärvi, I., Nohynek, L., Vaari, A., \& Mättö, J. (2006). Fibres as carriers for Lactobacillus rhamnosus during freezedrying and storage in apple juice and chocolate-coated breakfast cereals. International Journal of Food Microbiology, 112(2), 171178.

Salminen, S., Collado, M. C., Isolauri, E., \& Gueimonde, M. (2009). Microbial-host interactions: selecting the right probiotics and prebiotics for infants. Nestlé Nutrition Workshop Series: Pediatric program, 64, 201-217.

Santivarangkna, C., Kulozik, U., \& Foerst, P. (2006). Effect of carbohydrates on the survival of Lactobacillus helveticus during vacuum drying. Letters in Applied Microbiology, 42, 271-276.

Santivarangkna, C., Aschenbrenner, M., Kulozik, U., \& Foerst, P. (2011). Role of glassy state on stabilities of freeze-dried probiotics. Journal of Food Science, 76(8), R152-R156.

Semyonov, D., Ramon, O., \& Shimoni, E. (2011). Using ultrasonic vacuum spray dryer to produce highly viable probiotics. LWT- Food Science and Technology, 44, 1844-1852.

Shrestha, A. K., Howes, T., Adhikari, B. P., \& Bhandhari, B. R. (2008). Spray drying of skim milk mixed with milk permeate: effect of drying behavior, physicochemical properties and storage stability of powder. Drying Technology: An International Journal, 26, 239-247.

Sunny-Roberts, E. O., \& Knorr, D. (2009). The protective effect of monosodium glutamate on survival of Lactobacillus rhamnosus GG and Lactobacillus rhamnosus E-97800 (E800) strains during spray-drying and storage in trehalosecontaining powders. International Dairy Journal, 19, 209214.

Sunny-Roberts, E. O., \& Knorr, D. (2011). Cellural injuries on spray-dried Lactobacillus rhamnosus GG and its stability during food storage. Nutrition and Food Science, 41, 191200.

Sussich, F., \& Cesáro, A. (2000). Transitions and phenomenology of a, a-trehalose polymorphs inter-conversion. Journal of Thermal Analysis and Calorimetry, 62, 757-768. 
Tonon, R. V., Brabet, C., \& Hubinger, M. D. (2008). Influence of process conditions on the physicochemical properties of acai (Euterpe oleraceae Mart.) powder produced by spray drying. Journal of Food Engineering, 88(3), 411-418.

Ying, D. Y., Phoon, M. C., Sanguansri, L., Weerakkody, R., Burgar, I., \& Augustin, M. A. (2010). Microencapsulated Lactobacillus rhamnosus GG powders: relationship of powder physical properties to probiotic survival during storage. Journal of Food Science, 75, E588-E595.

Ying, D. Y., Sun, J., Sanguansri, L., Weerakkody, R., \& Augustin, M. A. (2012). Enhanced survival of spray-dried microencapsulated Lactobacillus rhamnosus GG in the presence of glucose. Journal of Food Engineering, 109, 597-602. 